\section{Matthias J. Reddehase and} Ulrich H. Koszinowski

Department of Virology, Institute for Microbiology, University of Ulm, Ulm

\section{Redistribution of critical major histocompatibility complex and $T$ cell receptor-binding functions of residues in an antigenic sequence after biterminal substitution*}

\begin{abstract}
Residues critical for establishing a trimolecular interaction with a major histocompatibility complex (MHC)-encoded receptor and a $\mathrm{T}$ cell antigen receptor (TcR) were determined for an antigenic nonapeptide. The $\mathrm{N}$-terminal residue proved to be involved in binding of the peptide to both receptors and the C-terminal residue was essential for MHC binding. While substitution of either of these critical terminal residues by alanine resulted in an almost complete loss of peptide antigenicity, simultaneous substitution of both created a new functional ligand for the same MHC molecule and the same TcR. Notably, in the biterminally substituted peptide, the core residues took on new roles in the trimolecular interaction in that a residue critical in the authentic nonapeptide for TcR binding became critical for $\mathrm{MHC}$ binding and former spacer residues became essential to various degrees for the interaction with either receptor or both. Thus, apparently, the loss of the terminal residues' contribution was at least partially compensated by a redistribution of the roles among the remaining residues. These results reflect a cooperative contribution of all residues of an antigenic peptide to its binding to both receptors and thus challenge a static definition of agretope and epitope as MHC and TcR binding sites.
\end{abstract}

\section{Introduction}

In molecular terms, antigen recognition by $T$ lymphocytes is a specific interaction between a TcR and an antigenic peptide bound to an MHC-encoded molecule [1-4]. While the geometry of the presumptive peptide binding site on MHC molecules is known [5, 6], possible binding conformations of peptides and the final interaction of the peptide-MHC complex with a TcR are still largely undefined. It is plausible to assume that amino acid side chains in an antigenic peptide specify its interaction with the two receptors in the trimolecular MHC-peptide-TcR complex. As a basis for predicting the structure of the bound peptide, residues essential for its binding to an MHC receptor and residues essential for its recognition by a TcR were distinguished by measuring the effects of amino acid substitutions [7-10]. Spacer residues were defined by not being critically involved in the interaction with either receptor [7]. Here we show an example in which double substitution by alanine at the two critical terminal positions of an antigenic nonapeptide restored the interaction with the same receptor pair. Interestingly, this antigenicity restoration was accompanied by a redistribution of the functions among the core residues.

[

* This work was supported by the Deutsche Forschungsgemeinschaft SFB 322, projects C4 (M. J. Reddehase) and B6 (U. H. Koszinowski).

Correspondence: Ulrich H. Koszinowski, Department of Virology, Institute for Microbiology, University of Ulm, Albert-EinsteinAllee 11, D-7900 Ulm, FRG

\section{Materials and methods}

\subsection{Cytolytic assay}

As effector in the antigenicity assay, a long-term line of CTL clone IE1 was used that remains active and specific without restimulation $[11,12]$, so that any interference with the assay by viral peptides from the CTL culture was excluded. Peptide synthesis, purification and quality control have been described $[13,14]$ and details of the assay were given previously [13].

\subsection{Competition assays}

\subsubsection{Autologous competition}

$L^{d}$-gene transfected $L$ fibroblasts, that is $L / L^{d}$ target cells, were incubated for $30 \mathrm{~min}$ with competitor peptide at graded molar concentrations in culture medium before antigenic peptide was added. After a further $60 \mathrm{~min}$, excess of both peptides was washed out and the cytolytic assay performed with CTL clone IE1. As antigenic peptides to be competed, YPHFMPTNL and APHFMPTNA were used at a constant, saturating concentration of $10^{-7} \mathrm{M}$ and $10^{-5} \mathrm{M}$, respectively.

\subsubsection{Heterologous competition}

P1.HTR tum ${ }^{+}$cells, a variant of mastocytoma P815.X2, served as target for recognition by CTL-P91:6 directed against tum- antigen $\mathrm{P} 91 \mathrm{~A}$ with $10^{-7} \mathrm{M}$ of peptide $\mathrm{P} \mathrm{A}^{-} .12-24$ as the antigenic peptide to be competed [15]. The MCMV IE1 protein (pp89) nonapeptide $P(168-176)$ YPHFMPTNL and its substituted analogs were tested as 
competitors. CTL-P91:6 were propagated by weekly restimulation with mutant P91 tum- cells [15].

\section{Results}

\subsection{Mapping of residues critical for receptor interaction}

The nonapeptide YPHFMPTNL (one-letter code) is presented by the murine MHC class I molecule $L^{d}$ to the TcR of the CTL clone IE1 [11-13]. Systematic shortening from both termini has identified the core sequence HFMPT as the minimal antigenic peptide recognized by IE1 [13]. It
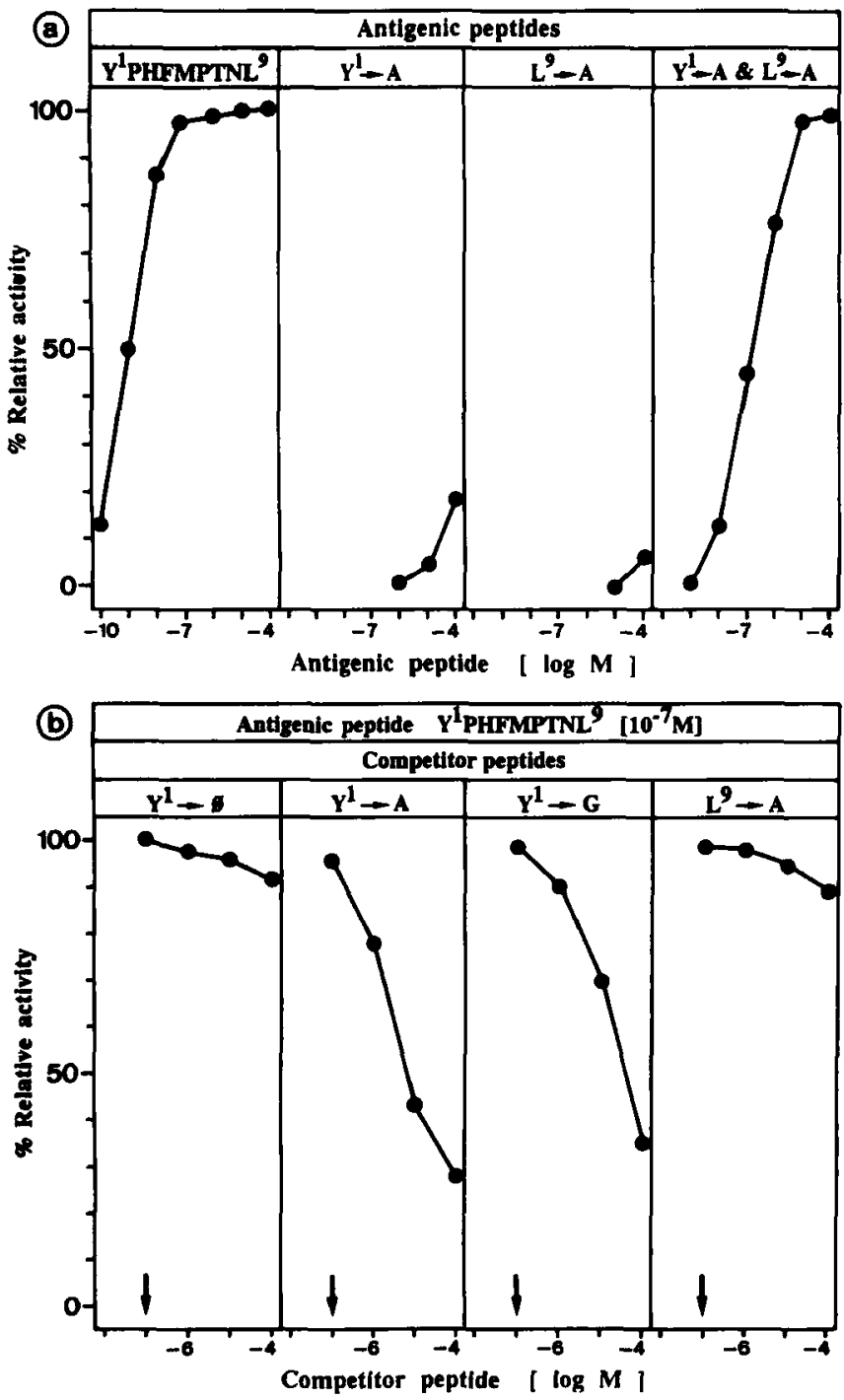

Figure 1. (a) Restoration of antigenicity by biterminal substitution. Cytolytic assays measuring lytic activity of CTL clone IE1 against $L^{d}$-gene transfected $L / L^{d}$ cells incubated with the indicated synthetic peptides. Data represent \% specific lysis standardized to the plateau lysis obtained with peptide YPHFMPTNL at an E/T plateau ratio of 10 , that was $61 \%$ in the documented experiment. No lysis was observed without antigenic peptide or when $L$ cells not expressing $\mathrm{L}^{\mathrm{d}}$ were used as targets. (b) Competitive capacity of terminally substituted or truncated $(\varnothing)$ analogs. $L / L^{d}$ target cells were preincubated with competitor peptides before incubation with the antigenic nonapeptide at a close-to-plateau concentration (arrows). was concluded previously that this core must encompass all residues needed for specifying the contact with the IE1 TcR and that the correct flanking residues enhance antigenicity mainly by improving the association with $L^{d}$. Despite the fact that even the isolated pentapeptide HFMPT was recognized, deletion [13] or substitution by Ala (Fig. 1a) of either one of the terminal residues $\operatorname{Tyr}^{1}(\mathrm{Y})$ and $\operatorname{Leu}^{9}(\mathrm{~L})$ of the nonapeptide destroyed antigenic potency almost entirely, which may mean that inappropriate flanking of the core forces it into a wrong conformation. Notably, simultaneous substitution of both critical residues largely restored antigenic potency (Fig. 1a). Probing the capacity of substituted peptides to compete with the unmodified nonapeptide revealed an MHC-binding quality of Leu ${ }^{9}$ and an ambivalent character of $\mathrm{Tyr}^{1}$ (Fig. 1b). While deletion of $\mathrm{Tyr}^{1}$ abrogated competitive ability, Ala or Gly in position 1 mediated significant competition, but not recognition by clone IE1. It is concluded that the peptide backbone in position 1 is crucial for $L^{d}$ binding of the peptide, while the side chain of $\operatorname{Tyr}^{1}$ is needed additionally for interaction with the IE1 TcR. Following this strategy of testing recognition and functional competition, the critical quality was determined for each position in the nonapeptide (Table 1). Competition against the unmodified autologous peptide, which is the classical version of the assay [7], allows for testing whether a nonantigenic analog can bind to the MHC molecule, but precludes an estimation of the binding strength relative to the unmodified antigenic peptide or to antigenic analogs with substitutions at spacer positions. This can be done, however, by competing the binding of an unrelated peptide to the same MHC molecule, in this case $\mathrm{L}^{\mathrm{d}}$, provided that the interaction affinities in the reference combination are in a similar order of magnitude or weaker. To date, besides the example discussed here, only two peptides have been identified in sequence that bind to $L^{d}$ $[15,16]$. Previous work has shown that YPHFMPTNL can efficiently compete with $\mathrm{L}^{\mathrm{d}}$-binding of tum ${ }^{-}$peptide $\mathrm{P} 91 \mathrm{~A}$ that is recognized by an anti-P91A CTL clone [15]. This system was therefore employed here for heterologous competition (Table 1). The two types of functional competition assays identified $\mathrm{Pro}^{2}$ and $\mathrm{Leu}^{9}$ as the most critical residues for MHC-binding of the peptide and $\mathrm{Phe}^{4}$ as the most critical residue for contacting the IE1 TcR. In contrast to a previous example [7], spacer residues were not found to be interspersed, but formed a contiguous tetrameric stretch $\mathrm{Met}^{5}(\mathrm{M})$ to $\mathrm{Asn}^{8}(\mathrm{~N})$.

\subsection{Multiple substitutions at the termini and at spacer positions}

Even though the biterminally substituted peptide APHFMPTNA is a more potent antigen than the $\mathrm{N}$ terminally substituted peptide APHFMPTNL (recall Fig. 1a), it is less potent in heterologous competition (compare Tables 1 and 2). This finding confirms the conclusion that Tyr $^{1}$ has an ambivalent character in that it contributes to the interaction of the peptide with both its receptors. In accordance with the previous result that the pentapeptide HFMPT is still antigenic [13], this core remained antigenic when flanked two-sided with two alanines in peptide AAHFMPTAA. Yet, MHC interaction of this minimal antigenic sequence was too weak for competing with the highly potent $L^{\mathrm{d}}$ binders YPHFMPTNL and tum $^{-}$ISTQNHRALPLVA (Table 2). 
Table 1. Pattern of MHC- and TcR-binding qualities of residues in the authentic nonapeptide

\begin{tabular}{|c|c|c|c|c|c|c|c|c|c|c|c|c|c|}
\hline \multicolumn{9}{|c|}{ Peptide sequence } & $\begin{array}{l}\text { Recognition by } \\
\text { IE } 1^{\text {a) }}\end{array}$ & $\begin{array}{l}\text { Autologous } \\
\text { competition }\end{array}$ & $\begin{array}{l}\text { Heterologous } \\
\text { competition }^{\text {c) }}\end{array}$ & \multirow{2}{*}{\multicolumn{2}{|c|}{$\begin{array}{l}\text { Main role of } \\
\text { residue }\end{array}$}} \\
\hline$Y^{1}$ & $\mathrm{P}^{2}$ & $\mathrm{H}^{3}$ & $F^{4}$ & $\mathbf{M}^{\mathbf{5}}$ & $\mathrm{P}^{6}$ & $T^{7}$ & $\mathbf{N}^{8}$ & $\mathrm{~L}^{9}$ & -11 to -10 & d) & 1 & & \\
\hline A & $\begin{array}{l}: \\
\text { A } \\
: \\
: \\
: \\
: \\
: \\
:\end{array}$ & $\begin{array}{l}\bullet \\
\dot{A} \\
\dot{\bullet} \\
\dot{\bullet} \\
\dot{\bullet} \\
\dot{\bullet}\end{array}$ & $\begin{array}{l}: \\
: \\
: \\
: \\
: \\
:\end{array}$ & $\begin{array}{l}\bullet \\
\bullet \\
\bullet \\
\bullet \\
\text { A } \\
\bullet \\
\bullet \\
\bullet \\
\bullet\end{array}$ & $\begin{array}{l}: \\
: \\
: \\
: \\
: \\
: \\
:\end{array}$ & $\begin{array}{l}: \\
\bullet \\
\bullet \\
: \\
: \\
: \\
:\end{array}$ & $\begin{array}{l}\bullet \\
\bullet \\
\bullet \\
\bullet \\
\bullet \\
\bullet \\
\bullet \\
\text { A } \\
\bullet\end{array}$ & $\begin{array}{l}: \\
: \\
: \\
: \\
: \\
: \\
: \\
\text { A }\end{array}$ & $\begin{array}{l}-5 \text { to }-4 \\
\text { Negative } \\
-4 \text { to }-3 \\
\text { Negative } \\
-12 \text { to }-11 \\
-11 \text { to }-10 \\
-11 \text { to }-10 \\
-11 \text { to }-10 \\
-4 \text { to }-3\end{array}$ & $\begin{array}{c}2 \\
\text { Negative } \\
2 \\
1 \\
- \\
- \\
- \\
- \\
\text { Negative }\end{array}$ & $\begin{array}{c}2 \\
\text { Negative } f \\
2 \\
1 \\
0 \text { to } 1 \\
1 \\
1 \\
1 \\
\text { Negative }\end{array}$ & $\begin{array}{l}\mathrm{Y}^{1}: \\
\mathrm{P}^{2}: \\
\mathrm{H}^{3}: \\
\mathrm{F}^{4}: \\
\mathrm{M}^{5}: \\
\mathrm{P}^{6}: \\
\mathrm{T}^{7}: \\
\mathrm{N}^{8}: \\
\mathrm{L}^{9}:\end{array}$ & $\begin{array}{l}\text { Ambivalent } \\
\text { MHC-binding } \\
\text { Ambivalent } \\
\text { TcR-binding } \\
\text { Spacer } \\
\text { Spacer } \\
\text { Spacer } \\
\text { Spacer } \\
\text { MHC-binding }\end{array}$ \\
\hline
\end{tabular}

a) Minimal concentration $(\log M)$ of peptide required to measure threshold lysis with CTL clone IE1.

b) $\log$ excess of peptide required to reduce lysis with IE1 by $>50 \%$. Antigenic peptide YPHFMPTNL was used at $10^{-7} \mathrm{M}$.

c) Log excess of peptide required to reduce lysis with CTL-P91:6 by $>50 \%$. Antigenic peptide P91 A ${ }^{-} .12-24$ was used at $10^{-7} \mathrm{M}^{-}$

d) Test not possible.

e) No recognition at $10^{-3} \mathrm{M}$.

f) No reduction of lysis at a $10^{3}$-fold excess over the antigenic peptide.

Table 2. Effect of biterminal and multiple spacer substitutions on antigenicity and competition capacitya)

\begin{tabular}{|c|c|c|c|c|c|c|c|c|c|c|c|}
\hline \multicolumn{9}{|c|}{ Peptide sequence } & \multirow{2}{*}{$\begin{array}{l}\text { Recognition by } \\
\text { IE1 } \\
-11 \text { to }-10\end{array}$} & \multirow{2}{*}{$\begin{array}{l}\text { Autologous } \\
\text { competition } \\
-\end{array}$} & \multirow{2}{*}{$\begin{array}{c}\text { Heterologous } \\
\text { competition } \\
1\end{array}$} \\
\hline $\mathbf{Y}^{1}$ & $\mathbf{p}^{2}$ & $\mathbf{H}^{\mathbf{3}}$ & $F^{4}$ & $M^{\mathbf{s}}$ & $\mathrm{P}^{6}$ & $\mathbf{T}$ & $\mathbf{N}^{\mathbf{B}}$ & $\mathrm{L}^{9}$ & & & \\
\hline $\begin{array}{l}\mathbf{A} \\
\mathbf{A} \\
:\end{array}$ & $\stackrel{\bullet}{\mathbf{A}}$ & & & $\begin{array}{l}\bullet \\
\stackrel{\bullet}{\mathbf{A}} \\
\mathbf{P}\end{array}$ & $\begin{array}{l}\bullet \\
: \\
\mathbf{A} \\
\mathbf{P}\end{array}$ & $\begin{array}{l}\bullet \\
\dot{\mathbf{P}}\end{array}$ & $\begin{array}{l}\stackrel{\bullet}{\mathbf{A}} \\
\mathbf{A} \\
\mathbf{P}\end{array}$ & $\begin{array}{l}\mathbf{A} \\
\mathbf{A} \\
\vdots\end{array}$ & $\begin{array}{l}-9 \text { to }-8 \\
-5 \text { to }-4 \\
\text { Negative } \\
\text { Negative }\end{array}$ & $\begin{array}{l}\text { - } \\
\text { Negutive } \\
\text { Nogative } \\
1\end{array}$ & $\begin{array}{c}3 \\
\text { Negative } \\
\text { Negative } \\
0-1\end{array}$ \\
\hline
\end{tabular}

a) Legend as for Table 1 .

The fact that spacer positions in YPHFMPTNL are not interspersed, but consecutive, opened the opportunity to follow the approach of homo-oligo-amino-acid spacing described by Maryanski et al. [17] with the extension that YPHF....L analogs encompass not only all predicted MHCbut also all predicted TcR-binding residues. Even though, per definition, single Ala substitutions were tolerated in the spacer positions, the respective tetra-Ala analog was negative in both recognition and functional competition (Table 2), strongly indicating that the spacer residues make a critical cooperative contribution to peptide antigenicity. In striking conformity with Maryanski's example, the

Table 3. Altered pattern of MHC- and TcR-binding qualities of core residues in the biterminally substituted analoga)

\begin{tabular}{|c|c|c|c|c|c|c|c|c|c|c|c|c|}
\hline \multicolumn{9}{|c|}{ Peptide sequence } & \multirow{2}{*}{$\begin{array}{c}\text { Recognition by } \\
\text { IE1 } \\
-9 \text { to }-8\end{array}$} & \multirow{2}{*}{$\begin{array}{c}\text { Autologous } \\
\text { competition }^{b} \\
-\end{array}$} & \multirow{2}{*}{\multicolumn{2}{|c|}{$\begin{array}{l}\text { Main role } \\
\text { of residue }\end{array}$}} \\
\hline $\mathbf{A}$ & $\mathbf{p}^{2}$ & $\mathbf{H}^{3}$ & $F^{4}$ & $\mathbf{M}^{5}$ & $\mathbf{P}^{\boldsymbol{\sigma}}$ & $T^{7}$ & $\mathbf{N}^{8}$ & $\mathbf{A}$ & & & & \\
\hline : & $\begin{array}{l}\text { A } \\
\bullet \\
\bullet \\
\vdots \\
\bullet \\
\bullet\end{array}$ & $\begin{array}{l}\bullet \\
\mathbf{A} \\
\bullet \\
\bullet \\
\bullet\end{array}$ & $\begin{array}{l}\bullet \\
\bullet \\
A \\
\bullet \\
\bullet \\
\bullet\end{array}$ & $\begin{array}{l}\bullet \\
\bullet \\
: \\
: \\
: \\
\bullet\end{array}$ & $\begin{array}{l}\bullet \\
\bullet \\
\bullet \\
\bullet \\
\text { A } \\
\bullet \\
\bullet\end{array}$ & $\begin{array}{l}\bullet \\
\bullet \\
: \\
: \\
:\end{array}$ & $\begin{array}{l}\bullet \\
: \\
: \\
: \\
: \\
\end{array}$ & $\begin{array}{l}\bullet \\
\bullet \\
\bullet \\
\bullet \\
\bullet \\
\bullet\end{array}$ & $\begin{array}{l}\text { Negative } \\
\text { Negative } \\
\text { Negative } \\
\text { Negative } \\
\text { Negative } \\
\text { Negative } \\
\text { Negative }\end{array}$ & $\begin{array}{c}\text { Negative } \\
3 \\
\text { Negative } \\
1 \\
2 \\
3 \\
\text { Negative }\end{array}$ & $\begin{array}{l}\mathbf{P}^{2}: \\
\mathbf{H}^{3}: \\
\mathbf{F}^{4}: \\
\mathbf{M}^{5}: \\
\mathbf{P}^{6}: \\
\mathbf{T}^{\mathbf{T}}: \\
\mathbf{N}^{\mathbf{8}}:\end{array}$ & $\begin{array}{l}\text { MHC-binding } \\
\text { Ambivalent } \\
\text { MHC-binding } \\
\text { TER-binding } \\
\text { Ambivalent } \\
\text { Ambivalent } \\
\text { MHC-binding }\end{array}$ \\
\hline
\end{tabular}

a) Legend as for Table 1 .

b) Log excess of peptide required to reduce lysis with CTL clone IE1 by $>50 \%$. As the antigenic peptide to be competed, APHFMPTNA was used at $10^{-5} \mathrm{M}$. No analog of the series was able to compete with recognition of peptide P91A-12-24 by CTL-P91:6. 
tetra-Pro analog proved to be a very potent functional competitor.Yet, importantly, this analog was not recognized by clone IE1 (Table 2).

\subsection{Redistribution of the critical contribution of core residues after biterminal substitution}

In view of the fact that peptide APHFMPTNA lacks residues critically involved in receptor interactions, recognition by CTL clone IE1 is a puzzling observation. We were considering two possibilities. Firstly, the terminal residues could balance each other, so that substitution of either one is deleterious, while substitution of both restores the original receptor interactions of the remaining residues. In that case one would expect an unchanged distribution of functional qualities among the core residues. Alternatively, the core residues might take on new roles in the substituted peptide to compensate the loss. Specifically, former spacer residues should then take a critical part. This is precisely what was observed (Table 3). Most prominently, $\mathrm{Phe}^{4}(\mathrm{~F})$ that was the main $\mathrm{TcR}$ contact residue in the original nonapeptide turned into a critical MHC-binding residue and all spacer residues became essential to varying degrees for binding to $\mathrm{L}^{\mathrm{d}}$ or for interacting with the IE1 TeR.

\section{Discussion}

The example shown here documents a considerable degree of flexibility in the roles individual residues can take when a peptide interacts with its receptors. It has been concluded before by other groups that different TcR may see different aspects of a particular peptide bound to a particular MHC molecule and, likewise, that a particular peptide may be presented by different or mutated MHC molecules in different configurations $[8,18]$, so that each residue of a given peptide has the potential to interact with either receptor or both, and the receptors determine which roles the residues actually take. Yet, our example is essentially different in that MHC and TcR were both kept constant. The observed redistribution of roles among the residues thus reflects an intrinsic flexibility of the peptide ligand that is not induced by changes in the receptors.

The conformations that peptides can adopt as they are bound by MHC molecules are the subject of controversal views. A helical model postulating separate facades of the peptide for binding to the MHC molecule and the TcR [19] was in agreement with the distribution of MHC- and TcR-binding qualities in a peptide described by Allen et al. [7] and also with the recognition of hybrid peptides with shuffled facades as reported by Rothbard et al. [14]. In contrast, from the observation that permissible substitutions at positions critical for MHC binding specified mutually exclusive recognition by either of two TcR, Sette et al. proposed an extended conformation for the bound peptide [8] and Maryanski et al. predicted an extended hairpin conformation, based on a competitor analog in which MHC-binding residues were spaced by conformation-constraining oligo-Pro [17]. In our example residues critical for binding to both receptors were retained by replacing only the spacer stretch by tetra-Pro. From the finding that this tetra-Pro analog was a potent competitor for the unmodified peptide but not a potent antigen, one must conclude that antigenic conformations cannot be predicted from conformations of competitor analogs. This conclusion is further substantiated by the finding that the same tetra-Pro analog was equally potent in competing with the unrelated tum- ${ }^{-} 91 \mathrm{~A}$ peptide.

One has to assume either that peptide APHFMPTNA resembles peptide YPHFMPTNL or that a conformational difference is tolerated by the IE1 TcR. One reasonable possibility is that interactions made by spacer residues were not critical and therefore remained cryptic in the highaffinity nonapeptide, but became critical and thus visible in the substituted low-affinity analog. That spacer residues are collectively involved in the formation of an antigenic complex is unambiguously documented by the loss of antigenic and competitive capacity in the tetra-Ala spacer analog.

In summary, to disclose the full involvement of all residues in receptor interaction, substitution analysis was needed not only for the authentic antigenic peptide but also for a low-affinity analog. The ambivalent character seen then for many residues is not easily compatible with models postulating spatial segregation of MHC- and TcR-binding residues. We propose that the function of a residue that is revealed in the assay does not describe its direct interaction with a receptor but rather its prevailing contribution to the cooperative effect of all residues. The redistribution of critical qualities observed in the present example is a direct reflection of residue cooperation.

We thank Dr. T. Boon for providing the CTL clone specific for antigen P91A. The expert technical assistance of Ms. Irene Huber and Jutta Neckermann, and the secretarial help of Ms. Ingrid Bennett is gratefully acknowledged. Dr. Margarita del Val contributed helpful discussion.

Received January 4, 1991; in revised form March 9, 1991.

\section{References}

1 Schwartz, R. H., Annu. Rev. Immunol. 1985. 3: 237.

2 Kourilsky, P. and Claverie,J.-M., Adv. Immunol. 1989. 45: 107.

3 Townsend, A. and Bodmer, H., Annu. Rev. Immunol. 1989. 7: 601 .

4 Chen, B. P. and Parham, P., Nature 1989. 337: 743.

5 Bjorkman, P. J., Saper, M. A., Samraoui, B., Bennett, W. S., Strominger, J. L. and Wiley, D. C., Nature 1987. 329: 512.

6 Garrett,T. P. J., Saper, M. A., Bjorkman, P. J., Strominger, J. L. and Wiley, D. C., Nature 1989. 342: 692.

7 Allen, P. M., Matsueda, G. R., Evans, R. J., Dunbar, Jr., J. B., Marshall, G. R. and Unanue, E. R., Nature 1987. 327: 713.

8 Sette, A., Buus, S., Colon, S., Smith, J. A., Miles, C. and Grey, H. M., Nature 1987, 328: 395.

9 Fox, B. S., Chen, C., Frage, E., French, C. A., Singh, B. and Schwartz, R. H., J. Immunol. 1987. 139: 1578.

10 Lorenz, R. G., Tyler, A. N. and Allen, P. M., J. Exp. Med. 1989. 170: 203.

11 Reddehase, M. J., Bühring, H. J. and Koszinowski, U. H., J. Virol. 1986. 57: 408.

12 Reddehase, M. J., Zawatzky, R., Weiland, F., Bühring, H.-J., Mutter, W. and Koszinowski, U. H., Immunobiology 1987. 174: 420 .

13 Reddehase, M. J., Rothbard, J. B. and Koszinowski, U. H., Nature 1989. 337: 651. 
14 Rothbard, J. B., Lechler, R. J., Howland, K., Bal, V., Eckels, D. D., Sekaly, R., Long, E. O., Taylor, W. R. and Lamb, J. R., Cell 1988. 52: 515.

15 Lurquin, C., Van Pel, A., Mariame, B., De Plaen, E., Szikora, J.-P., Janssens, C., Reddehase, M. J., Lejeune, J. and Boon, T., Cell 1989. 58: 293.

16 Schultz, M., Aichele, P., Vollenweider, M., Bobe, F. W.,
Cardinaux, F., Hengartner, H. and Zinkernagel, R. M., Eur. J. Immunol. 1989. 19: 1659.

17 Maryanski, J. L., Verdini, A. S., Weber, P. C., Salemme, F. R. and Corradin, G., Cell 1990. 60: 63.

18 Bhayani, H. and Paterson, Y., J. Exp. Med. 1989. 170: 1609.

19 DeLisi, C. and Berzofsky, J., Proc. Natl. Acad. Sci. USA 1985. 82: 7048 . 